\title{
The Relationship between Coal Consumption and Economic Growth in Indonesia
}

\author{
Irwandi \\ Master of Science in Economics Program, Faculty of Economics and Business Universitas Gadjah Mada Indonesia
}

\begin{abstract}
Indonesia is one of the largest coal producer countries in the world. In the previous research, it is stated that coal producer countries are able to affect economic growth. The purpose of the study is to investigate the cointegration and causal relationships between coal consumption and income in Indonesia for the period of 19652016 using Granger causality test based on Vector Error Correction Model (VECM) employing population as the control variable in bivariate system. The Augmented Dicky-Fuller (ADF) and Phillips-Perron (PP) tests were used to determine the variable stationarity. From Johansen's co-integration tests, it is indicated that there is a long-run relationship between the variables. The empirical study shows that there is no causal relationship between coal consumption and economic growth in Indonesia since coal consumption in fact cannot affect economic growth in Indonesia. Export tax becomes government revenues earned from energy sectors including coal.
\end{abstract}

Keywords: coal consumption, economic growth, causality, VECM, Indonesia

\section{Introduction}

Energy has a broad and significant role for all countries. Energy, whose abilities are to maintain various ecological processes, mobilize various economic activities, and improve the quality of life becomes one of determinants for the survival of society and country. Budiarto (2011) said that the availability of energy is one of basic human needs because it affects the way people manage materials and agricultural products; cook; illuminate the room; provide educational, health, facilities, telecommunication, and entertainment facilities; and so forth. Energy consumption is a vital source of people's lives

Nature provides many sources of energy. The non-renewable resources are the main source of energy. Non-renewable resources include fossil-fuel energy supplies: oil, gas, coal, minerals, copper, and nickel. Among the energy sources, coal is the most widely used energy source until now. Coal is the most abundant source of energy in the world and has a big role as a reliable energy source (World Coal Association, 2006). Coal is one of the mining products that is often used as a source of energy, especially in the power generation sector. The availability of coal is abundant and inexpensive when compared to petroleum and natural gas (Anoruo, 2017). According to the 2017 statistical review of world energy, China was the largest coal producer in 2016 while Indonesia was ranked as the fifth coal producing country in the world.

In Indonesia, coal and other energy sources such as oil and natural gas play an important role in the economic progress because energy contributes to state revenues in the form of taxes (Reksohadiprojo, 1988). The number of coal production and consumption in Indonesia grows well every year. In 2016, coal production amounted to 255.7 million tons of oil equivalent and coal consumption of 62.7 million tons of oil equivalent. The graph below illustrates the development of coal production and consumption in Indonesia from 1981-2016.

Since the study of Kraft and Kraft (1978) on energy consumption and income (GNP) in which they proved the existence of unidirectional causality between income (GNP) and energy consumption of USA's case in the period of 1947-1974, 
research about energy consumption and economic growths have grown and become a widespread interest of economists and policy makers. There have been many studies linking the two components. Bloch et al. (2012) show that under the supply-side analysis exists unidirectional causality running among coal consumption and income and under the demandside analysis exists unidirectional causality running between income and coal consumption in China. On the contrary, Ocal et al. (2013) reported that there was no Granger causality between coal consumption and economic growths in Turkey. Different analysis produces different results. Empirical evidence will encourage clear understanding of the importance of causal relationships between coal consumption and economic growths because it has implications for policies of national and international energy conservation.

\section{Figure 1. Coal Production and Consumption in Indonesia}

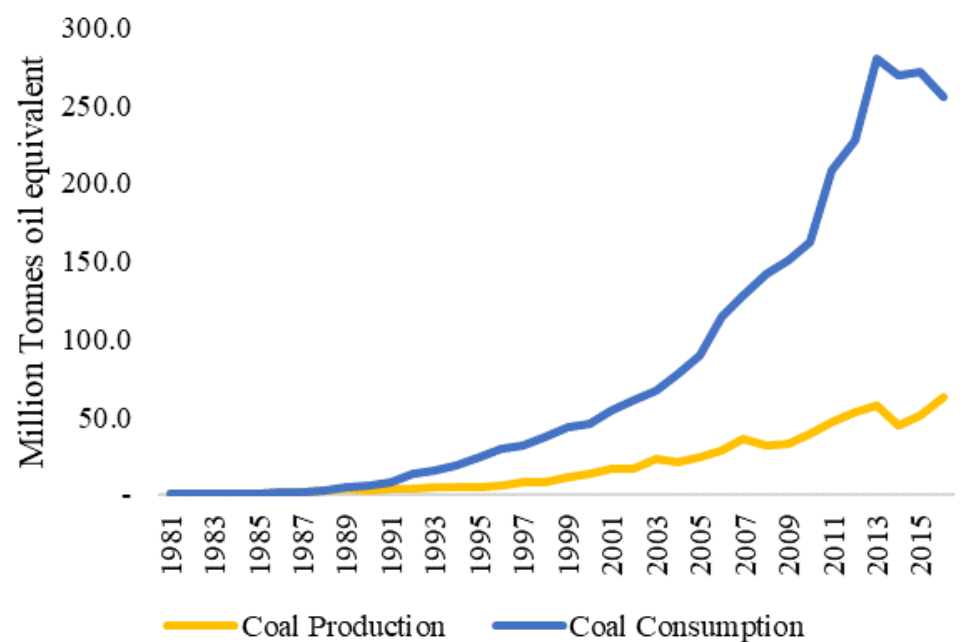

Source: BP Statistical Review of World Energy in June 2017

The earlier studies concerning the case of Indonesia; such as Masih dan Masih's (1996) indicate that there is a causal relationship between economic growth and energy consumption. Asafu-Adjaye (2000) also concludes that unidirectional Granger causality runs between energy and income in Indonesia. In line with the findings, Harsono and Kuncoro (2013) found that there was a unidirectional short run relationship running between electricity consumption per capita and GDP per capita in Indonesia. They used electricity consumption as a proxy of energy consumption. Fatai et al. (2004) also found a unidirectional causal relationship between energy and income. In contrast, Soytas and Sari (2003) indicated there was no co-integration because the ADF test with assume intercept and trend indicates a non-existence of a unit root in levels.

The purpose of the study is to investigate the co-integration and causality relationships between coal consumption and income in Indonesia using Granger causality test based on Vector Error Correction Model (VECM) involving the new data of coal consumption and GDP per capita as well as adding a variable control.

The rest of the article is structured as follows. Section 2 provides some surveys of literature about the causal relationships between coal consumption and economic growth. Section 3 presents data and methodology. Section 4 discusses the empirical results. Section 6 gives conclusion.

\section{Literature Review}

The purpose of this study is to examine the causal relationship between coal consumption and economic growth in Indonesia. Since study of Kraft and Kraft (1978) found that economic growth had a positive impact on energy consumption in the USA, research on this subject keep on grow. Below, some empirical discoveries on this subject. In general, there are four viewpoints to see the causal relationship between coal consumption and economic growth.

The first viewpoint is there is no causal relationship between coal consumption and economic growth. This implies that government policies for conservation and expansion of consumption energy will not influence economic growth. Sadr et al., 
(2012) examined the causal relationships between energy consumption and economic growth for OPEC countries by using the error-correction models (ECM) and analyzing the time series of the variables for the test of direction of Granger causality. The results showed that in the cases of Qatar, Saudi Arabia, and Nigeria, energy, economic growth, and prices were not mutually causal. For the others, there were causal relationships. Ocal et al. (2013) supported the idea stating that there was no Granger causality between coal consumption and economic growth in Turkey. This study used asymmetric causality techniques over the period of 1980-2006.

The second viewpoint indicates that a unidirectional causal relationship exits between economic growth and energy consumption. This considers that an increase in economic growth will increase coal consumption. Li and Leung (2012) in their paper investigated the relationship between coal consumption and the real GDP of China. Li and Leung (2012) analyzed twenty three provinces of China under a panel of co-integration and error-correction modeling (ECM) framework. One of the results is unidirectional causal relationship from GDP to coal consumption in Western regions. Fatai et al. (2004) tested Granger causality in New Zealand and Australian data and compared the results from a previous a study of four Asian countries: India, Indonesia, the Philippines, and Thailand. The New Zealand and Australian data were taken from the 1960-1999 International Energy Agency (IEA) database. Fatai et al. (2004) used coal, oil, gas, electricity and total final energy consumption variables. Issues in the literature were discussed and application of standard Granger causality tests, the Toda and Yamamoto approach, and the ARDL approach were used to show the energy-GDP relationship. The result indicated that there was unidirectional link between real GDP and commercial/industrial energy consumption in New Zealand and also evidence of a unidirectional link between real GDP and total final energy consumption. Similar relationships were found for Australia; while for four other Asian Economies had difference results.

Lei et al. (2014) tested the causal relationships between coal consumption and economic growth in six biggest coal consumption countries for the period of 2000-2010 using the panel data model and coal price as a third variable. According to the data of the International Energy Agency (IEA) in 2012, China, the United States of America (USA), India, Germany, Russia and Japan were the top six biggest countries which consumed the most coal throughout the world in 2010. The empirical finding suggested that a unidirectional causality between economic growth and coal consumption exists in China. For other countries, the researchers found difference results. Kalyoncu et al., (2013) tested the causal relationship between energy consumption and economic growth in Georgia, Azerbaijan, and Armenia for the 1995-2009 periods. Engle-Granger co-integration and Granger causality tests were used for Georgia and Azerbaijan. These two variables are co-integrated in case of Armenia. Thus, causality analysis was carried out for Armenia, the results of which reveal that there is unidirectional causality from per capita GDP to per capita energy consumption for Armenia.

The third opinion shows that there is a unidirectional causal relationship between energy consumption and economic growth. This indicates that expansion of consumption energy has significantly impact to economic growth. Lee and Chang (2008) studied the causal relationship between energy consumption and real GDP within a multivariate framework that included capital stock and labor input for sixteen Asian countries during the 1971-2002 period and used heterogeneous panel co-integration and panel-based error correction models to re-investigate co-movement. This study employed the modified aggregate production function. The empirical results supported a positive long-run, co-integrated relationship between real GDP and energy consumption. This result founded that long-run unidirectional causality run between energy consumption and economic growth but causal relationship between economic growth and energy consumption in short-run was lacking. Soytas and Sari (2003) in their study about the causality relationship between energy consumption and income (GDP) in G-7 countries and emerging markets, using co-integration and vector error correction techniques supported that there was unidirectional link between real energy consumption and GDP in Turkey, France, Germany and Japan; whereas in Italy and Korea, the causality run between GDP and energy consumption and in Argentina, there was a bi-directional causality. Asafu-adjaye (2000) showed that the unidirectional Granger causality run between energy and income in India and Indonesia, while bidirectional Granger causality run between energy and income in Thailand and the Philippines. In the long run, there was unidirectional Granger causality running between energy and prices and income in India and Indonesia. However, in the case of Thailand and the Philippines, energy, income and prices were mutually causal. This study used Maximum likelihood procedures to analyze the time series properties of the variables. For testing the direction of Granger causality, error-correction models were used.

The fourth opinion indicates that there is a bidirectional causality between energy consumption and economic growth. Akinlo (2008) used ARDL bound tests and Granger causality test within VECM model to investigate the co-integration and causality relationships between energy consumption and income in eleven countries in sub-Saharan Africa for the period 
of 1980-2003. The results in this study concluded that bidirectional relationship existed between energy consumption and economic growth for Gambia, Ghana, and Senegal. Moreover, in the case of Sudan and Zimbabwe, research results showed that economic growth Granger caused energy consumption. On the contrary, to the case of Cameroon and Cote D'Ivoire, the Granger causality test showed no causality between energy consumption and economic growth. Asafu-adjaye (2000) supported that the bidirectional Granger causality run between energy and income in Thailand and the Philippines and Razali et al., (2016) indicated that a bidirectional causality existed between income per capita and energy consumption in Malaysia during the 1971-2014 period. ADF and KPSS tests were used to unit root and ARDL Bound test were applied for long run co-integration relation between the variables both in single equation static as well as multivariate dynamic cointegration analysis that was applied.

\section{Data and Methodology}

\section{Data}

This empirical study used the annual time series data of per capita GDP (GDP) and coal consumption (CC) for the period of 1965-2016. The data period was selected based on the availability of coal consumption. The data of GDP were obtained from GDP per capita (constant 2010 US\$) of World Development Indicators produced by the World Bank. CC was from BP statistical review of world energy of June 2017 measured in million ton oil equivalent. This study also used control variables to avoid simultaneity bias in its regression (Gujarati and Porter, 2008). Population (POP) is a control variable (Razali et al., 2016). The data of a control variable were taken from the World Development Indicators produced by the World Bank. Including population variable as control variable in a bivariate system. All data on this study were transformed into natural logarithms to reduce heteroscedasticity. Eviews 8.0 was used to estimate the unit roots, co-integration tests, Granger causality tests, and VECM.

\section{Methodology}

This study adopted modeling strategy based on the widely used method of Engle-Granger (Granger \& Newbold, 1974; Engle \& Granger, 1987). Stationarity tests were applied through the unit test of root to determine whether the variables used were stationary or not. The Augmented Dicky-Fuller (ADF) and Phillips-Perron (PP) tests were used to determine the variable stationarity (Dickey and Fuller, 1981; Phillips and Perron, 1988). Spurious regression occurred in the estimation process if the times series data were not stationary. Data times were often not stationary at the level but linear combinations of two or more non-stationary data become stationary (Engle \& Granger, 1987). Furthermore, Engle-Granger states that the non-stationary time series data are claimed to be co-integrated. VECM was used when the time series data were not stationary at the level but stationary at first difference or second difference that indicated a theoretical relation between variables.

The next step was co-integration tests. The co-integration test used in this study was the Johansen test (Johansen, 1991). This co-integration test was used to determine the co-integration of a number of variables (vectors). The co-integration tests were conducted to investigate the existence of long-run relationships between the variables. After co-integration is found in the model, the residual value was used to validate the Vector Error Correction Model (VECM). VECM would assess the direction of causality between coal consumption and economic growth. The VECM equations adopted from Azlina (2012) state that:

$$
\begin{aligned}
& D L L C_{t}=\alpha_{1}+\sum_{i=1}^{p} \beta_{1 i} D L G D P_{t-1}+\sum_{i=1}^{p} \gamma_{1 i} D L C C_{t-1}+\sum_{i=1}^{p} \emptyset_{1 i} D L P O P_{t-1}+\theta_{1,1} E C T_{1_{t-1}}+\varepsilon_{1 t} \\
& D L G D P_{t}=\alpha_{2}+\sum_{i=1}^{p} \beta_{2 i} D L G D P_{t-1}+\sum_{i=1}^{p} \gamma_{2 i} D L C C_{t-1}+\sum_{i=1}^{p} \emptyset_{2 i} D L P O P_{t-1}+\theta_{2,1} E C T_{1_{t-1}}+\varepsilon_{2 t} \\
& L P O P_{t}=\alpha_{3}+\sum_{i=1}^{p} \beta_{3 i} D L G D P_{t-1}+\sum_{i=1}^{p} \gamma_{3 i} D L C C_{t-1}+\sum_{i=1}^{p} \emptyset_{3 i} D L P O P_{t-1}+\theta_{3,1} E C T_{1_{t-1}}+\varepsilon_{3 t}
\end{aligned}
$$

where CC is coal consumption, GDP is GDP per capita, and POP is population of Indonesia. First differences are denoted by $L$. The term ECTi refers to the error correction terms, derived from the long-run co-integrating relationship (i.e. $C C_{t}=$ $\left.\lambda_{1} G D P_{t}++\lambda_{2} P O P_{t}+\mu\right)$ where $\mu$ is the stationary residuals, $\alpha$ is intercepts, $\beta_{i j}, \gamma_{i j}$, and $\emptyset_{i j}$ a are coefficients, and $p$ is the lag lengths. In each equation, the right hand side variable is regressed with past values of itself and past values of other variables. 
The Granger causality test is applied by calculating the F-statistic based on the null hypothesis that the set of coefficient on the lagged values of independent variables are not statistically different from zero. Therefore, if the null hypothesis is rejected, then it is interpreted that the independent variable has causality on dependent variable. For instance, if the $\mathrm{F}$ statistic of the GDP (GDP as an independent variable in the equation (1) is significant at a $5 \%$ level or $1 \%$, then it is interpreted that there is a short-run causal effect running between GDP and CC. VECM also could estimate the long-run equilibrium, in addition to the detection of the short-run causal effects. In the ECT, the co-integrating vector (the long-run co-integrating relationships) represented the long-run equilibrium between variables. Therefore, the coefficient 1 for instance represented the long-run elasticity of consumption energy (CC) with respect to GDP per capita (GDP). In addition, the coefficient $i$ of the ECT measure the speed of adjustment towards the long-run equilibrium or the proportion of the longterm imbalance of the dependent variable that is corrected in each short-run period. Thus, the size and the statistical significance of this coefficient measure the extent to which each dependent variable has a tendency to return to its longrun equilibrium.

In accordance with the above statement, to detect the Granger causal relation, a joint $\mathrm{F}$ test is employed. Besides, the test for the long-run considered restrictions on the coefficient of ECT. This test is based on the null hypothesis that there is no Granger causality (i.e. the coefficients were zero, $\theta_{i}=0$ ). The Granger causal relation in the long-run use the t-test. In addition, the joint significance of the lags of explanatory variable (CC and GDP) and the lagged error correction term (ECM) are also performed to test for the Granger causality. In the coal consumption equation (1), the test for Granger causality of income is $H_{0}: \beta_{1}=\theta_{1,1}=\theta_{1,2}=0$. If the hypothesis null rejected, it suggest that there is Granger causality between GDP and coal consumption. In the GDP equation (2), the test for Granger causality of energy is $H_{0}: \gamma_{2}=\theta_{2,1}=\theta_{1,2}=$ 0 . If the hypothesis null is rejected, it suggested that there was Granger causality from coal consumption to coal GDP.

\section{Findings and Discussion}

Table 1 reports results of the ADF and PP tests on the model with an intercept and time trend. Unit root tests are sensitive to the presence of deterministic regression. Results of both tests indicate that all series on each variable (CC, GDP, and POP) are concluded to be stationarity. It can be seen that the null hypothesis of non-stationarity cannot be rejected at the $1 \%$ level of all variables. However, at the level all the variables are not stationarity. Stationarity of the data is in the first difference. The result indicates that all variables are integrated and can estimate the next tests. Co-integration test will be suitable to proceed with the long-run analysis.

The co-integration test uses Johansen's bivariate maximum likelihood procedure. The Johansen test considers two likelihood ratio tests for the co-integration rank, a trace test, and a maximum eigenvalue test. Table 2 shows result of Johansen co-integration tests. Both results of trace tests and maximum eigenvalue tests report the same conclusion that there are two co-integrated relationship at the $5 \%$ level of significance.

\section{Table 1 Results of Unit Root Tests}

\begin{tabular}{lll}
\hline $\begin{array}{l}\text { Augmented Dickey Fuller Test } \\
\text { Level }\end{array}$ & Philips-Perron Test \\
\hline LCC & -2.193228 & -2.320002 \\
LGDP & -2.442160 & -1.980496 \\
LPOP & -1.533001 & -1.980496 \\
\hline First Difference & & \\
\hline LCC & $-5.714891^{* * *}$ & $-5.724059^{* * *}$ \\
LGDP & $-5.486161^{* * *}$ & $-5.441510^{* * *}$ \\
LPOP & $-4.981215^{* *}$ & -1.060942 \\
\hline
\end{tabular}

Notes: The asterisks indicate the following level of significance: ${ }^{* * *} 1 \%$, ${ }^{* *} 5 \%$, and ${ }^{*} 10 \%$.

Table 2 Results of Johansen Co-integration Tests

\begin{tabular}{llll}
\hline Hypothesized No. of CE(s) & Lag & Trace Statistics & \multicolumn{1}{l}{$\begin{array}{l}\text { Maximum Eigenvalue } \\
\text { Statistics }\end{array}$} \\
\hline$r=0$ & & & $24.53832^{* *}$ \\
$r \leq 1$ & 3 & $37.82921^{* * *}$ & 10.57380 \\
$r \leq 2$ & 3 & 13.29089 & 2.717084 \\
\hline Normalized Co-integrating Coefficients & 3 & 2.717084 &
\end{tabular}

Normalized Co-integrating Coefficients 


\begin{tabular}{ll}
\hline Variables & Co-integrating vector \\
LCC & 1.000000 \\
LGDP & $14.69675(5.34847)$ \\
LPOP & $-51.45720(11.9188)$ \\
\hline
\end{tabular}

Notes: The asterisks indicate the following level of significance: ${ }^{* *} 1 \%$, ${ }^{* *} 5 \%$, and ${ }^{*} 10 \%$. Coefficient estimates express different elasticity. In brackets are standard errors.

Where $r$ represents the number of co-integrating vectors. A number of lags for each of the variables have been included in order to capture the short-run dynamics of the model. Each equation up to three lags, which should provide a sufficient representation of the process generating the data. The criteria optimal lag that gave is 3 lags.

\section{Tabel 3 VAR Lag Order Selection Criteria}

\begin{tabular}{lllllll}
\hline Lag & LogL & LR & FPE & AIC & SC & HQ \\
\hline 0 & 32.05305 & NA & $6.13 \mathrm{e}-05$ & -1.185839 & -1.070013 & -1.141895 \\
1 & 402.3051 & 680.0547 & $2.42 \mathrm{e}-11$ & -15.93082 & -15.46752 & -15.75504 \\
2 & 474.4000 & 123.5914 & $1.85 \mathrm{e}-12$ & -18.50612 & -17.69534 & -18.19852 \\
3 & 535.9390 & $97.96002^{*}$ & $2.20 \mathrm{e}-13^{*}$ & $-20.65057^{*}$ & $-19.49232^{*}$ & $-20.21113^{*}$ \\
\hline
\end{tabular}

Notes: * indicates lag order selected by the criterion. LR: sequentially modified LR test statistic (each test at $5 \%$ level). FPE: Final prediction error. AIC: Akaike information criterion. SC: Schwarz information criterion. HQ: Hannan-Quinn information criterion.

The existence of co-integration between coal consumption, GDP, gross fixed capital formation and population indicates that there is a long-term relationship and there should be a quality Granger at least in one direction. The Granger causality test should be checked through VECM. Short-term and long-term relationships among variables can be figured out through VECM where normal causality tests cannot detect it. Table 4 shows the short-run Granger causality based on VECM for Indonesia. The presence or absence of causality in the model is tested through the F-test. The results show that there is no short-run causal relationship between coal consumption and GDP. If there is conservative or expansion in coal consumption, it will not affect economic growth in Indonesia. In addition, there is a causal relationship between coal consumption. A unidirectional causal relationship runs between population and energy consumption

\section{Tabel 4 Short-run Granger Causality Results Based on VECM}

\begin{tabular}{llll}
\hline \multirow{2}{*}{ Dependent Variable } & Short-run & Source of Causation (Independent Variable) \\
& DLCC & DLGDP & DLPOP \\
\hline \multirow{2}{*}{ DLCC } & - & 4.635761 & $19.09295(0.0003)^{\star * *}$ \\
& 0.178043 & $(0.2005)$ & 2.956694 \\
DLGDP & $(0.9811)$ & - & $(0.3984)$ \\
& 3.152865 & 1.053373 & - \\
DLPOP & $(0.3687)$ & $(0.7883)$ & - \\
\end{tabular}

Notes: Figures in the parentheses () are $p$ - value. The asterisks indicate the following level of significance: ${ }^{* * *} 1 \%$, ${ }^{* *} 5 \%$, and ${ }^{*} 10 \%$.

The long-run causality test can also be referred to as the ECT (Error-Correction-Term) test. In this study, ECT is adjusted to the long-run equation in VECM. Table 5 shows the approximate ECT coefficients that are significant in the coal consumption equation in Indonesia. In this case, the t-statistical test on the ECT coefficient gives an indication of the longrun causality relationship.

\section{Tabel 5 Long-run Granger Causality Results Based on VECM}

\begin{tabular}{|l|l|l|l|l|}
\hline \multirow{3}{*}{ Dependent Variable } & Long-run & Source of Causation (Independent vVriable) \\
\cline { 2 - 5 } & ECT $_{1}$ & $\begin{array}{l}\text { Joint (ECT and } \\
\text { DLCC) }\end{array}$ & Joint (ECT and DLGDP) & Joint (ECT and DLPOP) \\
\hline \multirow{2}{*}{ DLCC } & -0.064476 & - & $\begin{array}{l}6.020972 \\
(0.1106)\end{array}$ & 13.14531 \\
& {$[-2.32457]$} & - & $(0.0043)^{* * *}$ \\
\hline
\end{tabular}




\begin{tabular}{|l|l|l|l|l|}
\hline DLGDP & -0.006713 & $\begin{array}{l}1.058386 \\
(0.7871)\end{array}$ & - & $\begin{array}{l}2.589745 \\
(0.4593)\end{array}$ \\
\hline DLPOP & $1.1 .48592]$ & $\begin{array}{l}20.10888 \\
(0.0002)^{\star *}\end{array}$ & $\begin{array}{l}3.420298 \\
(0.3312)\end{array}$ & - \\
\hline
\end{tabular}

Notes: Figures in the parentheses ( ) are p-value and brackets [ ] are t-statistic, respectively. The asterisks indicate the following level of significance: ${ }^{* * *} 1 \%,{ }^{* *} 5 \%$, and ${ }^{*} 10 \%$.

Table 5 reports that there is no long run causality relationship between coal consumption and economic growth. This result is consistent with the result of short run causality. These findings indicate that any activity of coal consumption will not affect economic growth. The empirical result is different from the empirical study conducted by Masih and Masih (1996), Asafuadjaye (2000), and Harsono and Kuncoro (2013). They found that energy consumption and economic growth in Indonesia had a Granger causality relationship. Coal consumption is not a proxy of the energy consumption used by Masih and Masih (1996) and Asafu-adjaye (2000) but the overall energy source consumed in Indonesia. Harsono and Kuncoro (2013) used electricity consumption as a proxy of energy consumption. Soytas and Sari (2003) indicated that in the case of Indonesia, there was no co-integration because the ADF test with assume intercept and trend indicated a non-existence of a unit of root in levels so that the next process was to see the relation of causality by using VECM which VECM requires cointegration in estimation procedure.

In Indonesia, coal is the fourth largest energy consumption after feul, gas, and electrics while in terms of production, coal is the second largest production after gas. Most of coal production is exported therefore coal's role to economic growth in Indonesia can be observed from export activity where there will be governmnet revenue in tax form. This case is in accordance with the question of Reksohadiprojo (1988) which states that energy contributes to government revenues in the form of taxes.

\section{Conclusion}

Energy has a broad and significant role for the countries of the world. Energy becomes one of the determinants of the survival of society and country due to its ability to maintain various ecological processes, mobilize various economic activities, and improve the quality of life. This study analyzed the causal relationship between coal consumption and economic growth (GDP) in Indonesia for the period of 1965-2016 using the VECM approach. Population was involved as a control variable in this equation. The root test of the ADF and PP units and the Johansen co-integration test were used to stationarity of variables and co-integration before causality test. All data stationary are on first difference. The presence of long-term relationships was evidenced by all co-integration variables in lag 3. Using the Granger causality test concept and method, this study estimated short-term and long-term causal relationships. There is no relationship between coal consumption and economic growth in the short run and in the long run. This finding proves that hypothesis of no causal relationship between coal consumption and economic growth is true. The activity of coal consumption has no impact on economic growth.

In Indonesia as one of the largest coal-producing countries in the world, coal consumption has not yet had an impact on economic growth because coal is domestically consumed in little portion while most of the coal production is exported. Government revenue in the form of export tax may be the importance of coal's existence in Indonesia.

This finding is important for policy makers although the empirical study shows that there is no causality relationship between coal consumption and economic growth. Indonesia should invest more in technological innovations and improve industrial sectors in order to maximize coal utilization. Utilization of coal with modern technology aims to reduce the adverse effects on society and economy. The government should increase demand for coal in the domestic market in order to increase coal consumption because coal prices are low if compared to other energy sources and fluctuate in recent years. Hence, it would be better if it is utilized in this country. In addition, the researcher suggests similar research since there might be the relationship between the coal consumption and the economic growth may vary in different countries and as a reference to policies and decision making concerning coal consumption and economic growth in each country.

\section{Acknowledgments}

I would like to thank to Indonesia Endowment Fund for Education (LPDP) Ministry of Finance Republic Indonesia for gorgeously supporting author by scholarship. I am so grateful as well for Prof. Tri Widodo, M.Ec.Dev., Ph.D for giving this project and always encouraging author to accomplish it. My best gratitude for my parents, Abd. Halik and Halima, thanks 
for your pray. The last but not least, all my friends, Rifa'i, Maizul, Salman, Anshar, and Mahyudin for being together during working and finishing this paper.

\section{References}

[1] Akinlo, A. E. (2008). Energy Consumption and Economic Growth: Evidence from 11 Sub-Sahara African countries. Energy Economics, 30(5), 2391-2400.

[2] Anoruo, E. (2017). Coal Consumption and Economic Growth Nexus : Evidence from Bootstrap Panel Granger Causality Test. Panoeconomicus, 64(3), 255-271.

[3] Asafu-adjaye, J. (2000). The Relationship between Energy Consumption, Energy prices and Economic Growth : Time Series Evidence from Asian Developing Countries. Energy Economics, 22, 615-625.

[4] Azlina, A.A. (2012). Energy Consumption and Economic Development in Malaysia : A Multivariate Cointegration Analysis. Procedia - Social and Behavioral Sciences, 65, 674-681.

[5] Bloch, H., Rafiq, S., \& Salim, R. (2012). Coal Consumption, CO 2 Emission and Economic Growth in China : Empirical Evidence and Policy Responses. Energy Economics, 34, 518-528.

[6] Budiarto, Rachmawan. 2011. Kebijakan Energi Menuju Sistem Energi yang Berkelanjutan. Yogyakarta: Samudra Biru. (Energy Policy Towards Sustainable Energy System. Yogyakarta: Blue Ocean)

[7] Dickey, D. A., \& Fuller, W. A. (1981). Likelihood Ratio Statistics for Autoregressive Time Series with a Unit Root. Econometrica, 49(4), 1057-1072.

[8] Engle, R.F., \& Granger, C.W.J. (1987). Co-Integration and Error Correction : Representation, Estimation, and Testing. Econometrica, 55(2), 251-276.

[9] Fatai, K., Oxley, L., \& Scrimgeour, F. G. (2004). Modelling the causal relationship between energy consumption and GDP in New Zealand, Australia, India , Indonesia, The Philippines and Thailand. Mathematics and Computers in Simulation, 64, 431-445.

[10] Granger, C. W. J., \& Newbold, P. (1974). Spurious Regressions in Econometrics. Journal of Econometrics, 2, 111-120.

[11] Gujarati, D. N., \& Porter, D. (2008). Basic Econometrics. The McGraw-Hill.

[12] Harsono, T. D., \& Kuncoro, M. (2013). Electricity Consumption and Economic Growth : A Causality Evidence from Indonesia, 1984-2010. International Journal of Business, Economics and Law, 2(April), 8-9.

[13] Hossein, S.S.M., Yazdan, G.F., \& Hasan, S. (2012). Consideration the Relationship between Energy Consumption and Economic Growth in Oil Exporting Country. Procedia - Social and Behavioral Sciences, 62, $52-58$.

[14] Johansen, S. (1991). Estimation and Hypothesis Testing of Cointegration Vectors in Gaussian Vector Autoregressive Models. Econometrica, 59(6), 1551-1580.

[15] Kalyoncu, H., Gürsoy, F., \& Göcen, H. (2013). Causality Relationship between GDP and Energy Consumption in Georgia , Azerbaijan and Armenia. International Journal of Energy Economics and Policy, 3(1), 111-117.

[16] Kraft, J. and Kraft, A. 1978. On the Relationship between Energy and GNP. Journal of Energy and Development. 3(2), 401-403.

[17] Lee, C., \& Chang, C. (2008). Energy Consumption and Cconomic Growth in Asian Economies: A More Comprehensive Analysis Using Panel Data. Resource and Energy Economics, 30, 50-65.

[18] Lei, Y., Li, L., \& Pan, D. (2014). Study onThe Relationships Between Coal Consumption and Economic Growth of The Six Biggest Coal Consumption Countries: With Coal Price as A Third Variable. Energy Procedia, 61, 624-634.

[19] Li, R., \& Leung, G.C.K. (2012). Coal Consumption and Cconomic Growth in China. Energy Policy, 40, 438-443.

[20] Masih, A.M.M., \& Masih, R. (1996). Energy Consumption, Real Income and Temporal Causality: Results from A Multi-Country Study Based on Cointegration and Error-correction Modelling Techniques. Energy Economics, 18, 165-183.

[21] Ocal, O., Ozturk, I., \& Aslan, A. (2013). Coal Consumption and Economic Growth in Turkey, 3(2), 193-198.

[22] Phillips, P. C. B., \& Perron, P. (1988). Testing for A Unit Root in Time Series Regression. Biometrika, 75(2), 335-346.

[23] Razali, R., Khan, H., Shafie, A., \& Hassan, A. R. (2016). The Relationship between Energy Consumption and Economic Growth in Malaysia : ARDL Bound Test Approach. In AIP Conference Proceedings (Vol. 1787, pp. 80020-1-80020-7). 
[24] Reksohadiprojo. 1988. Ekonomi Energi. Yogyakarta: PAU Studi Ekonomi Universitas Gadjah Mada. (Energy Economics. Yogyakarta: PAU Economic Studies Universitas Gadjah Mada)

[25] Soytas, U., \& Sari, R. (2003). Energy Consumption and GDP: Causality Relationship in G-7 Countries and Emerging Markets, 33-37.

[26] World Coal Association, (2006). Coal facts. http://www.worldcoal.org/ 